\title{
Plasma-Enhanced Atomic Layer Deposition of Zirconium Oxide Thin Films and Its Application to Solid Oxide Fuel Cells
}

\author{
Jiwon Oh ${ }^{1, \dagger}$, Giwon Seo ${ }^{1,+}$, Jaehwan Kim ${ }^{1}$, Seungmuk Bae ${ }^{2}$, Jeong-Woo Park ${ }^{3}$ and Jin-Ha Hwang ${ }^{1, *}$ \\ 1 Department of Materials Science and Engineering, Hongik University, Seoul 04066, Korea; \\ jw3498@naver.com (J.O.); tjrldnjs917@nate.com (G.S.); jaehwan730@daum.net (J.K.) \\ 2 Research Facility Center, Kunsan National University, Jeollabuk-Do 54150, Korea; moki1492@kunsan.ac.kr \\ 3 R\&D Center Hansol Chemical Co., Ltd., Jeollabuk-Do 55321, Korea; jwpark@hansol.com \\ * Correspondence: jhwang@hongik.ac.kr; Tel.: +82-2-320-3069; Fax: +82-2-333-0127 \\ + These authors contributed equally to this work.
}

Citation: Oh, J.; Seo, G.; Kim, J.; Bae,

S.; Park, J.-W.; Hwang, J.-H.

Plasma-Enhanced Atomic Layer Deposition of Zirconium Oxide Thin Films and Its Application to Solid Oxide Fuel Cells. Coatings 2021, 11, 362. https://doi.org/10.3390/ coatings11030362

Academic Editor: Narottam P. Bansal

Received: 1 January 2021

Accepted: 17 March 2021

Published: 22 March 2021

Publisher's Note: MDPI stays neutral with regard to jurisdictional claims in published maps and institutional affiliations.

Copyright: (c) 2021 by the authors. Licensee MDPI, Basel, Switzerland. This article is an open access article distributed under the terms and conditions of the Creative Commons Attribution (CC BY) license (https:/ / creativecommons.org/licenses/by/ $4.0 /)$.

\begin{abstract}
Zirconium oxides were deposited using plasma-enhanced atomic layer deposition (PEALD) involving (2-(N-methylamino)1-MethylEthyleneCyclopentadienyl)Bis(DiMethylAmino)Zr (abbreviated as $\mathrm{CMEN-Zr}$ ) and oxygen plasma as zirconium and oxygen sources. The zirconium oxide thin films demonstrate temperature-independent growth rates per cycle of $0.94 \mathrm{~A} /$ cycle at $150-215^{\circ} \mathrm{C}$. The deposited $\mathrm{ZrO}_{2}$ thin films were characterized using numerous analytical tools, i.e., $\mathrm{X}$-ray photoelectron spectroscopy for chemical bonding state and composition, X-ray diffraction for crystallinity, atomic force microscopy for surface morphology, field-emission scanning electron microscopy for cross-sectional analysis, spectroscopic ellipsometry and UV-visible spectrophotometry for optical characterization, capacitance-voltage measurements for dielectric constants and atomic defects, and current-voltage characteristics for electrical information. The insulating features of the crystalline and stoichiometric $\mathrm{ZrO}_{2}$ films were implemented in the anode composites to evaluate the influence of ALD-based nano-features on the electrochemical performance of solid oxide fuel cells, with the main emphasis on anode performance. The presence of nanomaterials on Ni/YSZ anode composites is analyzed to determine the negative effects on electrochemical performance and the degradation of cell performance of solid oxide fuel cells (SOFCs). The artificial design was proven to be effective in controlling the cell performance as long as proper material design was adopted in SOFC electrodes.
\end{abstract}

Keywords: PEALD; CMEN-Zr; surface chemistry; solid oxide fuel cells

\section{Introduction}

The advent of the hydrogen economy in association with the fourth industrial revolution has ignited extensive research into solid oxide fuel cells (SOFCs) due to their academic and industrial applications. SOFCs have become one of the powerful next generation energy resources due to their unique advantages such as high operation efficiency, contamination-free fuel flexibility, and minimized pollution [1-4]. SOFCs are typically constructed using a multitude of dissimilar materials with a variety of physical and chemical properties, including cathodes, electrolytes, and anodes, in addition to subsidiary sealing and interconnect materials. To maintain the highly efficient operation of SOFCs at intermediate temperatures ranging from 650 and $800^{\circ} \mathrm{C}$, electrodes should be improved dramatically by minimizing polarization loss and improving ionic conductivity. There have been a few attempts involving artificial controls on triple phase boundary reactions based on the charge transfer between electronic/ionic carries and fuels, depending largely on the microstructure of electrodes and interfacial geometries adjacent to the ionic electrolyte [5-7].

Atomic layer deposition (ALD) has been established as a unique thin film deposition technique originating from chemisorption between the reactants and underlying substrates. Starting with the pioneering report by Suntola [8], self-limiting atomic layer deposition 
has been extended through low-temperature deposition, atomic scale thickness control, excellent step coverage characteristics of conformal coating, and conformal deposition of the materials under interest, all without limiting the electronic applications, including dynamic random access memory (DRAM), non-volatile random access memory, and metaloxide-semiconductor field effect transistors (MOSFETs) [9-12]. Recently, ALD has been applied to non-electronic applications such as sensors, solar cells, water-splitting catalysts and materials, secondary batteries, and fuel cells due to its ability to deposit mainly metal and oxide materials to three-dimensional complex material structures [13-17]. In particular, ALD has been adapted to three-dimensional interconnected microstructures by adding the ALD-based penetration capability, unlike the conventional ceramic processing techniques. The conformal features of atomic layer deposition can be employed to control oxide-based cathodes and anodes of solid oxide fuel cells in terms of performance improvement or performance degradation. In order to verify the applicability of atomic layer deposition in the electrochemical performance in SOFCs, the current work chose metal oxide materials with a special emphases on the degradation in SOFC cell performance. The roles of atomic layer deposition in SOFCs are discussed along with the processing designs with the aim of achieving optimized SOFC performance and stability.

To demonstrate the application of ALD-assisted surface modification concept, 2-(Nmethylamino)1-MethylEthyleneCyclopentadienyl)Bis(Dimethylamino)Zr (abbreviated as CMEN-Zr) was combined with oxygen plasma to deposit $\mathrm{ZrO}_{2}$ materials onto the $\mathrm{Ni} / \mathrm{YSZ}$ anode composites of SOFCs. The current work focuses on the atomic layer deposition of $\mathrm{ZrO}_{2}$ thin films involving a newly developed $\mathrm{Zr}$ precursor and its application to anode composites of SOFC materials, with the aim of controlling artificial cell performance by modifying the reactive sites present in porous electrodes. In addition, the potential of the atomic layer deposition of materials into solid oxide fuel cells is discussed in terms of the reliability and stability issues encountered in SOFCs.

\section{Experimental}

Zirconium oxide thin films were deposited using plasma-enhanced atomic layer deposition (PEALD) that employed CMEN-Zr (Hansol Chemical Co., Ltd., Seoul, Korea) as a zirconium precursor with oxygen plasma as an oxygen source. A PEALD system's flow of reactants and products, controlled in shower head mode, was utilized. One basic PEALD cycle was performed based on the following sequence: (CEMN-Zr supply)-(Ar purge)-( $\mathrm{O}_{2}$ plasma supply)-(Ar purge). The CMEN-Zr precursor was held at $70{ }^{\circ} \mathrm{C}$ to guarantee sufficient reactant molecules in the ALD reaction chamber, and the connecting lines were maintained at $110{ }^{\circ} \mathrm{C}$. The oxygen source was supplied using oxygen plasma at a power of $100 \mathrm{~W}$ and frequency of $13.56 \mathrm{MHz}$. The substrate temperature varied between $90^{\circ} \mathrm{C}$ and $215^{\circ} \mathrm{C}$ for zirconium oxide thin films, and the total chamber pressure was controlled to 0.53 Torr. The $\mathrm{Zr}$ precursor was preheated to $70{ }^{\circ} \mathrm{C}$ and the line was maintained at $110{ }^{\circ} \mathrm{C}$. The $\mathrm{Si}$ wafers were cleaned in the order of acetone $\left(\mathrm{CH}_{3} \mathrm{COCH}_{3} 99.5 \%\right.$, OCI Company, Seoul, Korea), methanol $\left(\mathrm{CH}_{3} \mathrm{OH} 99.9 \%\right.$, OCI Company, Seoul, Korea), and deionized water. Subsequently, the native oxide was removed using dilute hydrofluoric acid (HF: $48-51 \%$, J.T. Baker, NJ, USA).

The chemical states of elements, compositions, and trace element amounts in the films were analyzed after the $34 \mathrm{~s}$ Ar bombardment sputtering using X-ray photoelectron spectroscopy (XPS, K-alpha model, Thermo Fisher Scientific, Waltham, MA, USA). X-ray diffraction (XRD) measurements were performed using a high-sensitivity diffractometer (D-2000, Rigaku, Tokyo, Japan). Surface morphologies were obtained using an atomic force microscope (AFM, XE150, PSIA, Suwon, Gyeonggi-do, Korea). Ultraviolet-visible spectrometers (UV-2450, Shimadzu, Kyoto, Japan) were employed to measure the transmission. Capacitance-voltage measurements (HP 4192A low-frequency impedance analyzer, Hewlett-Packard, Palo Alto, CA, USA) and dc-based current-voltage characteristics (4155C semiconductor parameter analyzer, Agilent, Santa Clara, CA, USA) were made to obtain the electrical/dielectric parameters of insulating zirconium oxide thin films, respectively. 
The microstructure of the films was analyzed using high-resolution field-emission scanning electron microscopy (FE-SEM, S-4800, Hitachi, Tokyo, Japan). The optical thicknesses were measured using high-precision spectroscopic ellipsometers (UVISEL AGAX ER, Horiba, Kyoto, Japan and MG-1000-UV, Nano-view, Ansan, Gyeonggi-do, Korea).

This work employed commercial SOFC cells (Kceracell Co., Ltd., Boksu-myeon, Korea) in order to understand the role of ALD-based $\mathrm{ZrO}_{2}$ in the electrochemical performance. As shown in the schematic diagram of Figure 1, composite materials consisting of nickel oxide (NiO) and $3 \mathrm{~mol} \%$ yttria-stabilized zirconia (3YSZ) were used as anode layer materials with a thickness of $800-850 \mu \mathrm{m}$. Subsequently, the anode functional layer made up of $\mathrm{NiO}$ and $\left(\mathrm{Yb}_{2} \mathrm{O}_{3}\right)_{0.06}\left(\mathrm{Sc}_{2} \mathrm{O}_{3}\right)_{0.04}\left(\mathrm{ZrO}_{2}\right)_{0.9}(6 \mathrm{Yb} 4 \mathrm{ScSZ}, 10-15 \mu \mathrm{m})$ and the electrolyte layer (6 Yb4ScSZ, 10-15 $\mu \mathrm{m}$ ) were coated using the screen-printing method and then laminated and co-sintered. On the electrolyte layer, a buffer layer $(2-5 \mu \mathrm{m})$ was coated that consisted of $\mathrm{Gd}-\mathrm{Yb}$-Bi-Ce-O(GYBC), and heat treatment was performed. Afterward, a lanthanum strontium cobalt ferrite (LSCF)-Gd doped ceria (GDC) layer (5-10 $\mu \mathrm{m})$ and LSCF layer (20-25 $\mu \mathrm{m})$ were coated as a cathode functional layer and cathode layer, respectively. After heat-treatment, a low-temperature sintered cathode current collection (LTCCC) layer was coated (the detailed information on LTCCC is not available to the customers). The unit cell performance was quantified using a button cell with a size of $2 \mathrm{~cm} \times 2 \mathrm{~cm}$. The fabricated SOFC cells were placed between platinum mesh and nickel foam materials as charge-collecting metals for cathode and anode composites. The whole cell assembly was heated to $800{ }^{\circ} \mathrm{C}$, and a pressure of $15 \mathrm{kgf}$ was applied to the SOFC assembly to guarantee perfect sealing between the SOFC cathode and anode compartments. At $800{ }^{\circ} \mathrm{C}$, the mixture of $\mathrm{N}_{2}$ and $\mathrm{H}_{2}$ was controlled to the total flowrate of $200 \mathrm{sccm}$, and in order to reduce the NiO/YSZ anode composites to Ni/YSZ composites, which were initially $200 \mathrm{sccm} \mathrm{N}_{2}$, by progressively increasing the flowrate of $\mathrm{H}_{2}$ and decreasing the flowrate of $\mathrm{N}_{2}$ under the total flow rate of $200 \mathrm{sccm}$, and finally, they were $0 \mathrm{sccm} \mathrm{N}$ and $200 \mathrm{sccm}$ $\mathrm{H}_{2}$. After complete reduction, the air and hydrogen were supplied to both cathode and anode. On the reduced Ni/YSZ anode (the thickness of which was approximately $850 \mu \mathrm{m}$ ), $\mathrm{ZrO}_{2}$ was deposited by PEALD with twice the pulse time and Ar purge time (CMEN-Zr (from $2.5 \mathrm{~s}$ to $5 \mathrm{~s}$ ), $\mathrm{O}_{2}$ plasma (from $9 \mathrm{~s}$ to $18 \mathrm{~s}$ ), and Ar purge (from $60 \mathrm{~s}$ to $120 \mathrm{~s}$ )) because the reactants (i.e., zirconium and oxygen sources) needed to penetrate the porous reduced $\mathrm{Ni}$ /YSZ anode and the byproducts needed to be removed from the pore network. The deposition temperature was $150{ }^{\circ} \mathrm{C}$, which is within the ALD window, and the deposition cycle was 200 cycles. Open cell voltages, current-voltage and impedance spectroscopy characteristics were measured to determine the electric characteristics in the temperature range of $650-800{ }^{\circ} \mathrm{C}$ using 4-point measurements (biologic electrochemical system).

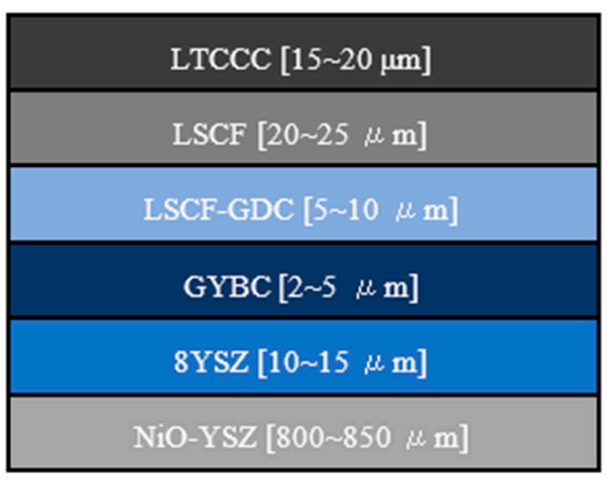

Figure 1. Schematic description of solid oxide fuel cells employed in the application of atomic layer deposition to energy-based devices.

\section{Results and Discussion}

Initially, Zr-based halogen compounds were studied, such as $\mathrm{ZrI}_{4}$ and $\mathrm{ZrCl}_{4}[18,19]$. However, strong corrosive byproducts such as $\mathrm{HCl}$ and $\mathrm{HI}$ unintentionally damaged the $\mathrm{ZrO}_{2}$ thin films deposited. To solve the issue, alkoxide and alkylamode-based $\mathrm{Zr}$ pre- 
cursors were developed, i.e., ZTB (Zirconium Tert-Butoxide; $\mathrm{Zr}\left[\mathrm{OC}\left(\mathrm{CH}_{3}\right)_{3}\right]_{4}$ ), TDMA-Zr (Tetrakis(DiMethylAmido)Zirconium $\left(\mathrm{Zr}\left(\left[\mathrm{CH}_{3}\right]_{2} \mathrm{~N}\right)_{4}\right)$, and TEMA-Zr (Tetrakis(EthylMethylAmido)Zirconium; $\mathrm{Zr}\left[\mathrm{N}\left(\mathrm{CH}_{3}\right)_{2}\left(\mathrm{C}_{2} \mathrm{H}_{5}\right)_{2}\right]$ ] [20-22]. The former alkoxide-based $\mathrm{ZrO}_{2}$ should be accompanied through the breakage of strong $\mathrm{Zr}-\mathrm{O}$, leading to a slower growth rate. Instead, alkylamide-based $\mathrm{ZrO}_{2}$ involved the weaker bond mediated between $\mathrm{Zr}$ and $\mathrm{N}$, leading to a faster growth rate. However, alkyl-amide-based $\mathrm{ZrO}_{2}$ suffered from thermal instability. After improvement in thermal stability at relatively high temperatures, the cyclopentadienyl ring was attached to its preceding alkylamide-based precursor, producing alkylamidocyclopentadiene compounds such as $\mathrm{ZAC}(($ Cyclopentadienyl)tris(dimethylAmino) Zirconium and $\left.\mathrm{CpZr}\left[\mathrm{N}_{(}\left(\mathrm{CH}_{3}\right)_{2}\right]_{3}\right)$ [23]. Continuously, $\mathrm{CPNZr}$ and CMEN-Zr were synthesized with the aim of increasing the corresponding thermal stability and crystallinity [24].

The current work employed a Zr-containing organometallic compound [2-(N-methylamino)1-MethylEthyleneCyclopentadienyl]Bis(DiMethylAmino)Zr, which is an Alkylamido-

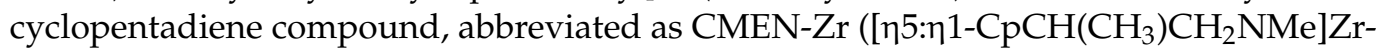
$\left.\left(\mathrm{NMe}_{2}\right)_{2}\right)$, where $\mathrm{C}$ is the $\mathrm{Cp}$ (cyclopentadienyl ring), $\mathrm{M}$ is the methyl group $\left(-\mathrm{CH}_{3}\right), \mathrm{E}$ is the ethylene bridge $\left(-\mathrm{C}_{2} \mathrm{H}_{2}-\right)$, and $\mathrm{N}$ is the $\mathrm{N}$-methylamino group $\left(-\mathrm{NHCH}_{3}\right)$. The detailed molecular structure is demonstrated in Figure 2.
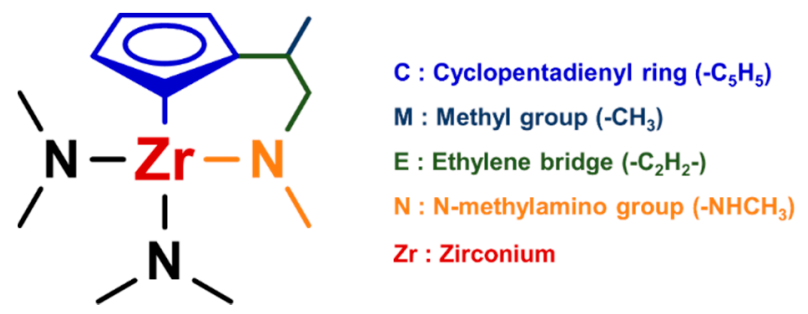

Figure 2. Molecular structure of CMEN-Zr employed in the plasma-enhanced atomic layer deposition of zirconium oxide thin films.

The pulse-time dependences for the CMEN-Zr precursor and oxygen plasma were performed at $150{ }^{\circ} \mathrm{C}$, as shown in Figure $3 \mathrm{a}, \mathrm{b}$. The saturation conditions were $2.5 \mathrm{~s}$ and $9 \mathrm{~s}$ for CMEN-Zr precursor and oxygen plasma, respectively. The cycle dependence was investigated at $150{ }^{\circ} \mathrm{C}$, taking into account the saturation states of CMEN-Zr and oxygen plasma sources, as shown in Figure 3c. The linear dependence of the deposited thickness on ALD cycle numbers allows empirical determination of the growth per cycle, 0.94 A/Cycle. Finally, the pre-determined conditions of CMEN-Zr and oxygen plasma sources were monitored as a function of temperature, as shown in Figure 3d. The ALD windows were found to exist from $140^{\circ} \mathrm{C}$ to $215^{\circ} \mathrm{C}$. Furthermore, there was a possibility of higher temperatures as an upper bound for the surface limiting ALD windows.

The chemical states and compositions of the CMEN-Zr-based $\mathrm{ZrO}_{2}$ were investigated using XPS analysis, which Figure 4a shows in the survey spectrum along with the core spectra of $\mathrm{Zr} 3 d$ and $\mathrm{O} 1 \mathrm{~s}$ displayed in Figure $4 b, c$. As shown in Figure $4 b, c$, the $\mathrm{Zr} 3 \mathrm{~d}$ and $\mathrm{O} 1$ s peaks were found to be 182.8 and $530.7 \mathrm{eV}$, respectively, and their positions are in reasonable agreement with the reported literature [25-27]. From the XPS quantification of the $\mathrm{Zr} 3 \mathrm{~d}$ and $\mathrm{O} 1 \mathrm{~s}$ peaks, the $\mathrm{Zr}$ and $\mathrm{O}$ compositions were determined to be 36.02 and 59.61 atom percentiles, leading to an approximate stoichiometric ratio of one to two for the $\mathrm{Zr}$ versus $\mathrm{O}$ elements. No zirconium oxide thin films included significant amounts of carbon or nitrogen contamination, i.e., the contents were below the detection limit of XPS. 

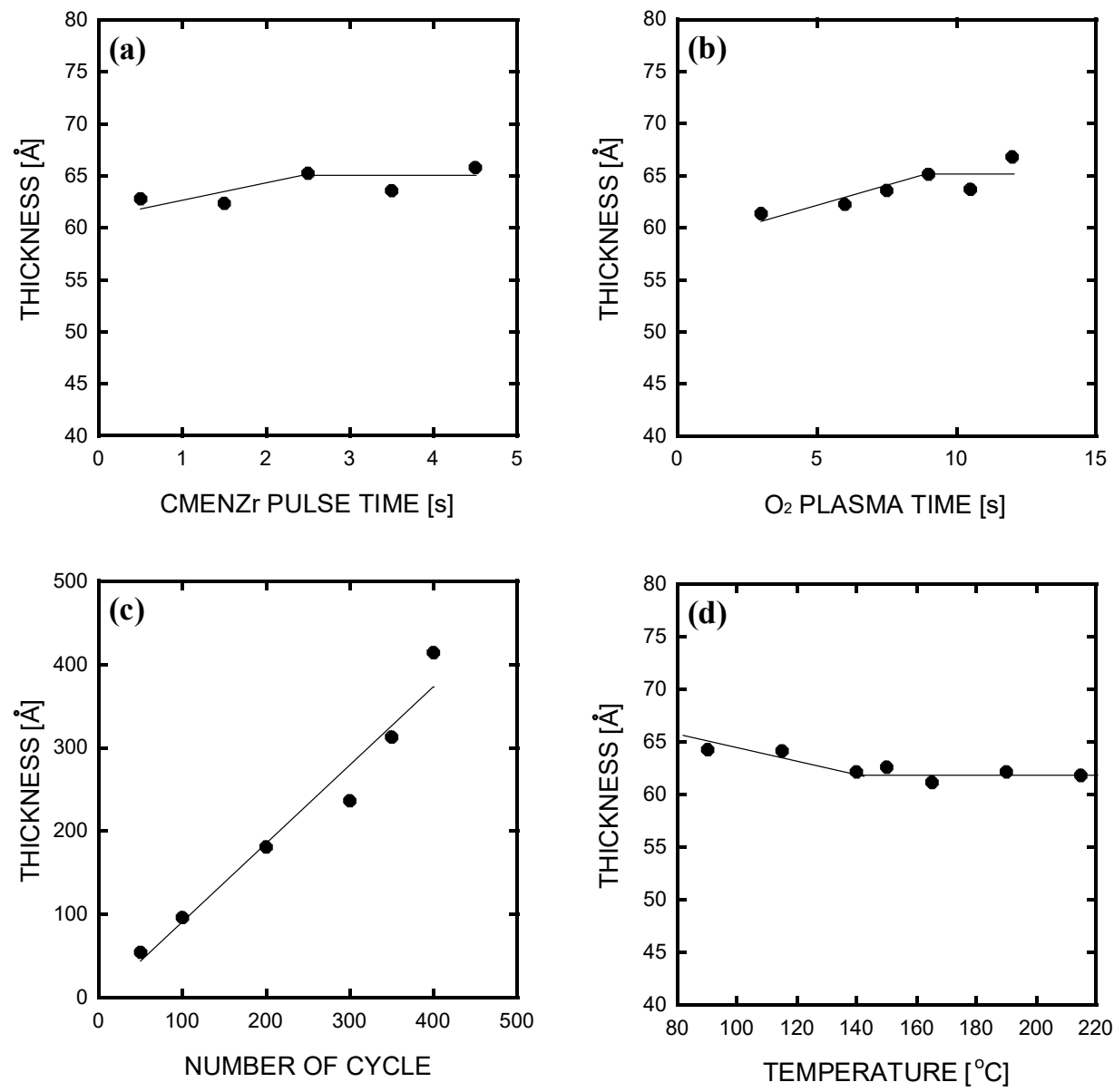

Figure 3. Empirical condition for atomic layer deposition involving CMEN-Zr and oxygen plasma for zirconium and oxygen sources, respectively. (a) Deposition temperature: $150{ }^{\circ} \mathrm{C}, \mathrm{O}_{2}$ plasma pulse time: $12 \mathrm{~s}$, (b) deposition temperature: $150{ }^{\circ} \mathrm{C}, \mathrm{CMEN}-\mathrm{Zr}$ pulse time: $4.5 \mathrm{~s}$, (c) cycle dependence of CMEN-Zr-based $\mathrm{ZrO}_{2}$ deposition (CMEN-Zr pulse time: $2.5 \mathrm{~s}, \mathrm{O}_{2}$ plasma pulse time: $9 \mathrm{~s}$ ) and (d) temperature dependence of ALD deposition (temperature: $150{ }^{\circ} \mathrm{C}, \mathrm{O}_{2} \mathrm{CMEN}-\mathrm{Zr}$ pulse time: $2.5 \mathrm{~s}$, plasma pulse time: $9 \mathrm{~s})$.
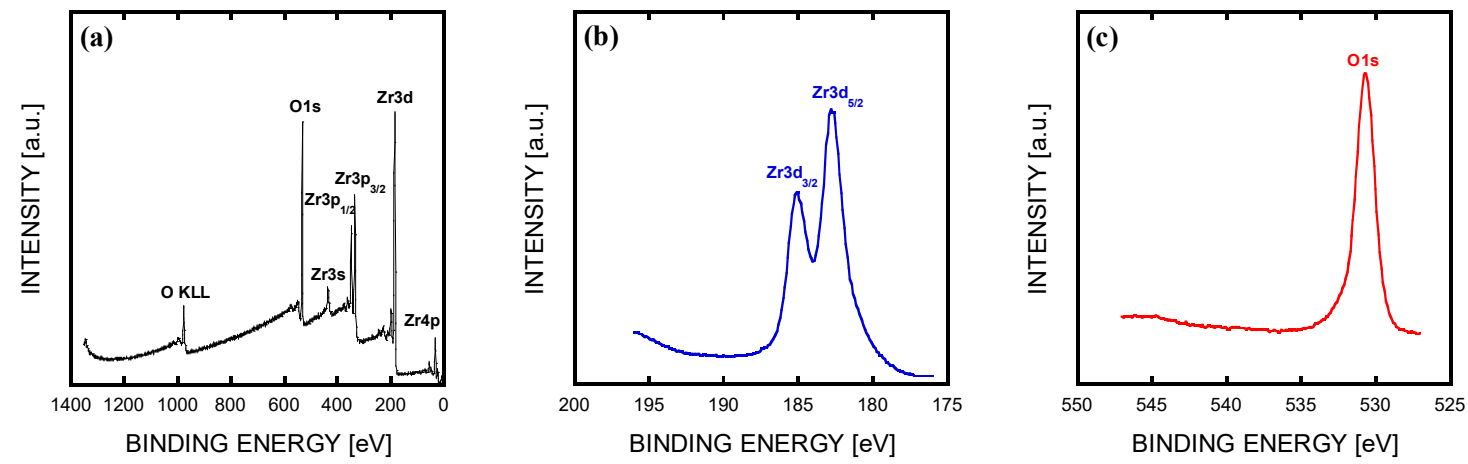

Figure 4. X-ray photoelectron spectrometry of ALD-based $\mathrm{ZrO}_{2}$ thin films: (a) survey spectrum, (b) core spectrum of $\mathrm{Zr} 3 \mathrm{~d}$, (c) core spectrum of $\mathrm{O} 1 \mathrm{~s}$. Sample information: deposition temperature: $150{ }^{\circ} \mathrm{C}, \mathrm{CMEN}-\mathrm{Zr}$ pulse time: $2.5 \mathrm{~s}, \mathrm{O}_{2}$ plasma pulse time: 9 s, PEALD cycle: 400 cycles $(\sim 38 \mathrm{~nm})$, substrate: P-type silicon.

X-ray diffraction was performed to evaluate the crystallinity of $\mathrm{ZrO}_{2}$-based thin films. As shown in Figure 5, the empirical X-ray diffraction information was compared in terms of the reported crystal structures, e.g., monoclinic and tetragonal structures whose JCDPS peaks were found in JCPDS No. 98-065-8755 and 98-065-5671, respectively. 
The tetragonal peaks were indexed as (011), (110), (112), and (121), while the (11-1) peak of the monoclinic structure was located at $2 \theta=28.182^{\circ}$. The current CMEN-Zr-based $\mathrm{ZrO}_{2}$ thin films were present according to the characteristic of the structural composites composed of two different crystalline structures. The mixture of monoclinic and tetragonal $\mathrm{ZrO}_{2}$ materials have mainly been reported at the semiconductor/dielectric interfaces, although a monoclinic structure was detected in the structural analyses $[19,28,29]$.

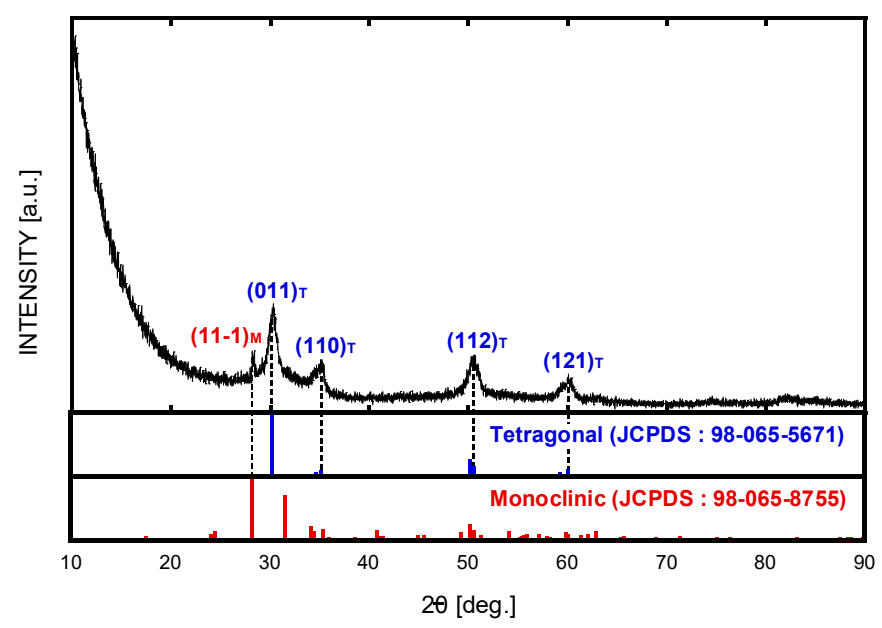

Figure 5. X-ray diffraction acquired from the ALD-based $\mathrm{ZrO}_{2}$ thin films. Deposition temperature: $150{ }^{\circ} \mathrm{C}, \mathrm{CMEN}-\mathrm{Zr}$ pulse time: $2.5 \mathrm{~s}, \mathrm{O}_{2}$ plasma pulse time: $9 \mathrm{~s}$, PEALD cycle: 300 cycles $(\sim 27 \mathrm{~nm})$, substrate: P-type silicon.

The cross-sectional electron micrographs are shown in Figure 6a along with the crystalline features, indicating the non-flat features of the top thin film surface. From the AFM analysis results of Figure 7, the mixed crystalline phases seemed to produce a larger RMS compared to the Si bare specimen, where the $\mathrm{ZrO}_{2}$ thin films and bare Si exhibited $0.27 \mathrm{~nm}$ and $0.113 \mathrm{~nm}$, respectively. Taking into account the deposited thickness (of approximately $32.3 \mathrm{~nm}$ ), the normalized RMS was less than 1\%, which was superior to the preceding $\mathrm{ZrO}_{2}$ results and could be considered as smooth in a relative manner, despite the $X$-ray diffraction analysis characteristic of the existence of crystalline phases. The surface roughnesses have been reported to range from 3.5\% to $5.7 \%$ after the normalization based on the thickness of the $\mathrm{ZrO}_{2}$ thin films under test, except for less than $1 \%$ in the $\mathrm{ZrO}_{2}$ deposited using $\mathrm{Zr}$ amide precursors [21,23,24,30-32]. The current $\mathrm{ZrO}_{2}$ thin films demonstrated a highly smooth surface morphology characteristic of the superior RMS value (which is equivalent to less than $1 \%$ in terms of ratios normalized based on thickness).

The optical UV-visible transmission was monitored to confirm the transparent features of the ALD-based $\mathrm{ZrO}_{2}$ thin films between 300 and $800 \mathrm{~nm}$ and included the ultraviolet and visible light regimes. The optical transmittance increased monotonically with increasing photonic wavelength. The lowest transmittance of $76.6 \%$ was measured at a wavelength of $300 \mathrm{~nm}$, and the highest transmittance of $95.5 \%$ was measured at $800 \mathrm{~nm}$ (see Figure 8). As shown in Figure 9, the as-deposited $\mathrm{ZrO}_{2}$ thin films exhibited an order of $10^{-6} \mathrm{~A} / \mathrm{cm}^{2}$. However, the annealed $\mathrm{ZrO}_{2}$ thin films showed an improved leakage current density of approximately $10^{-7} \mathrm{~A} / \mathrm{cm}^{2}$. 

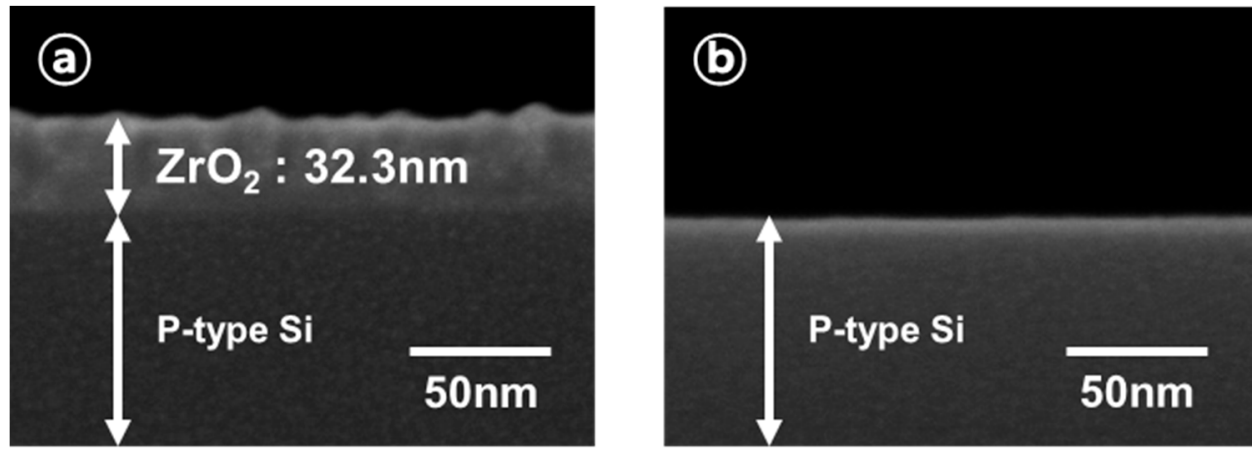

Figure 6. Cross-sectional electron microscopy analysis of (a) CMEN-Zr-based $\mathrm{ZrO}_{2}$ thin films and (b) bare Si substrates. Deposition temperature: $150^{\circ} \mathrm{C}, \mathrm{CMEN}-Z \mathrm{r}$ pulse time: $2.5 \mathrm{~s}, \mathrm{O}_{2}$ plasma pulse time: $9 \mathrm{~s}$, PEALD cycle: $350 \mathrm{cycles}(\sim 30 \mathrm{~nm})$, substrate: P-type silicon.
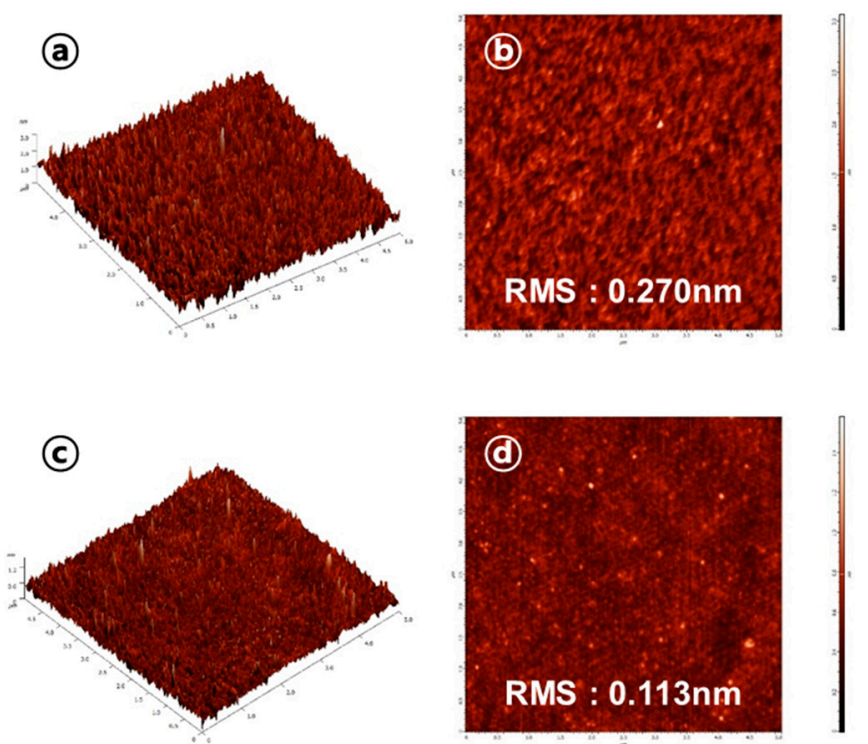

Figure 7. Atomic force microscopy analysis of CMEN-Zr-based $\mathrm{ZrO}_{2}$ thin films. (a,b) ALD-deposited $\mathrm{ZrO}_{2}$ thin films (deposition temperature: $150{ }^{\circ} \mathrm{C}, \mathrm{CMEN}-\mathrm{Zr}$ pulse time: $2.5 \mathrm{~s}, \mathrm{O}_{2}$ plasma pulse time: 9 s, PEALD cycle: 300 cycles $(\sim 27 \mathrm{~nm}))$, (c,d) Si substrate: P-type silicon.

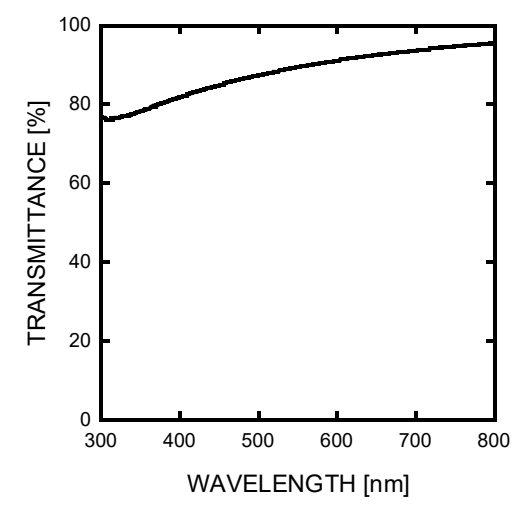

Figure 8. UV-visible spectrophotometric analysis of ALD-deposited $\mathrm{ZrO}_{2}$ thin films (deposition temperature: $150{ }^{\circ} \mathrm{C}, \mathrm{CMEN}-\mathrm{Zr}$ pulse time: $2.5 \mathrm{~s}, \mathrm{O}_{2}$ plasma pulse time: $9 \mathrm{~s}$, PEALD cycle: 350 cycles $(\sim 30 \mathrm{~nm})$, substrate: borosilicate glass). 


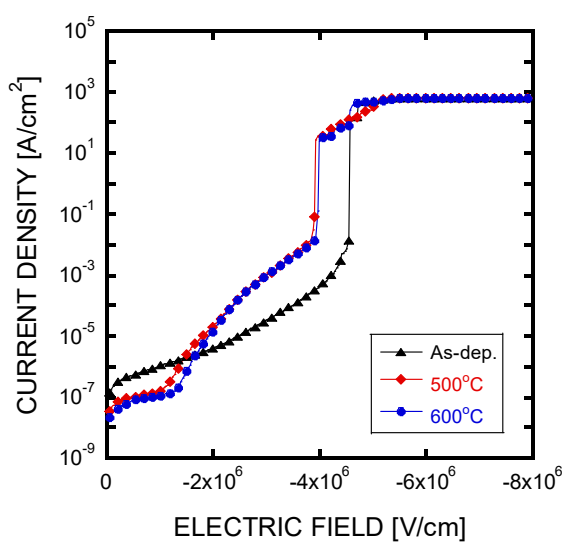

Figure 9. Current-voltage characteristics of ALD-based $\mathrm{ZrO}_{2}$ using $\mathrm{CMEN}-\mathrm{Zr}$ and oxygen plasma as zirconium and oxygen sources, respectively: as-deposited, annealed at $500{ }^{\circ} \mathrm{C}$, and annealed at $600{ }^{\circ} \mathrm{C}$.

The improved electrical performance is attributed to the improvement in crystallinity, which is dependent on the thermal annealing and interfacial traps. The breakdown voltage was measured to approximately $4 \mathrm{MV} / \mathrm{cm}$. The dielectric information was extracted from capacitance-voltage measurements on the as-deposited films and annealed at $500{ }^{\circ} \mathrm{C}$ and $600{ }^{\circ} \mathrm{C}$, as shown in Figure 10. The dielectric constant of $\mathrm{ZrO}_{2}$ thin films was calculated to be from 22.9 and 25.2. These empirical dielectric constants are in agreement with prior reports, even though they exhibited a higher constant than has been previously reported.
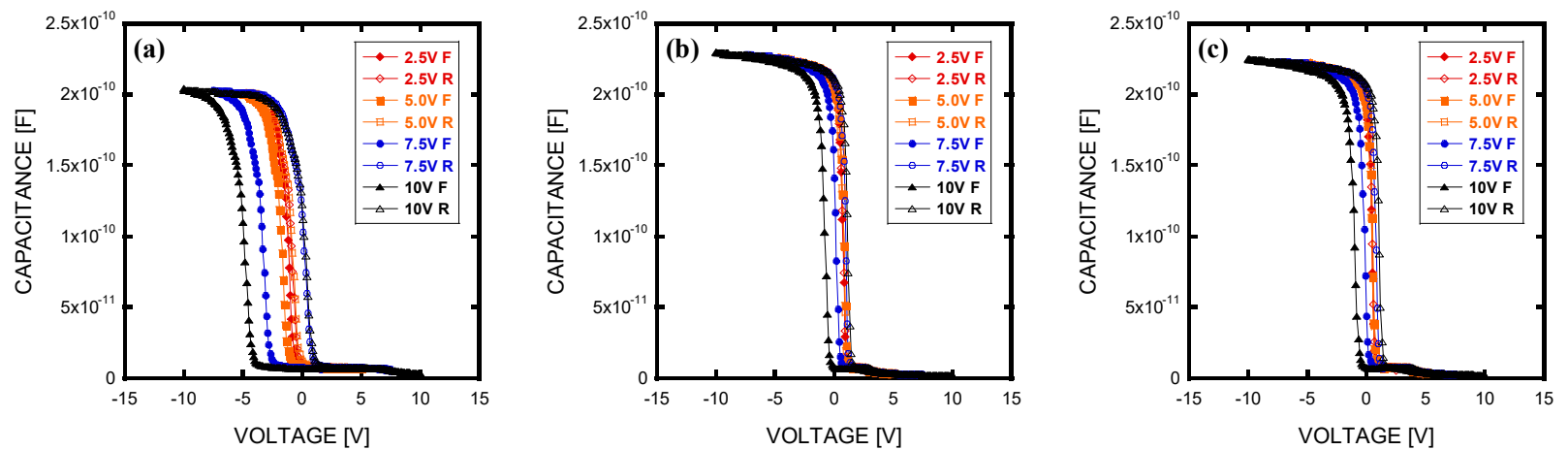

Figure 10. Capacitance-voltage measurements of ALD-based $\mathrm{ZrO}_{2}$ using $\mathrm{CMEN-Zr}$ and oxygen plasma as zirconium and oxygen sources, respectively: (a) as-deposited, (b) annealed at $500{ }^{\circ} \mathrm{C}$ and (c) annealed at $600{ }^{\circ} \mathrm{C}$.

Furthermore, the flat band voltage hysteresis decreased from $5.6 \mathrm{~V}$ for the as-deposited $\mathrm{ZrO}_{2}$ and 1.9 and $2.0 \mathrm{~V}$ for the annealed $\mathrm{ZrO}_{2}$ thin films at 500 and $600{ }^{\circ} \mathrm{C}$, respectively. Based on the capacitance-voltage measurement and current-voltage characteristics, the electrical and dielectric information can be extracted. Table 1 compares the electric and dielectric characteristics obtained from ALD-based $\mathrm{ZrO}_{2}$ thin films. The current $\mathrm{ZrO}_{2}$ thin films demonstrate that the CMENZr-based $\mathrm{ZrO}_{2}$ thin films are classified as high- $\mathrm{k}$ dielectric materials featuring low leakage current density and high breakdown electric fields despite relatively large flat band voltage hysteresis compared to those of the $\mathrm{ZrO}_{2}$ thin films reported previously $[18,19,21,30-32]$. 
Table 1. Summarized electrical and dielectric characteristics obtained from the current $\mathrm{ZrO}_{2}$ and reported $\mathrm{ZrO}$ thin films.

\begin{tabular}{|c|c|c|c|c|c|c|c|}
\hline & $\mathrm{ZrI}_{4}$ & ZTB & $\begin{array}{c}\mathrm{Zr}(\mathrm{MEA})_{2} \\
(\text { guan-MEA })_{2}\end{array}$ & $\mathrm{Cp}_{2} \mathrm{Zr}\left(\mathrm{CH}_{3}\right)_{2}$ & Zr-AMD & ZAC & CMEN-Zr \\
\hline ALD type & $\begin{array}{l}\text { Thermal } \\
\text { ALD }\end{array}$ & PEALD & Thermal ALD & $\begin{array}{l}\text { Thermal } \\
\text { ALD }\end{array}$ & $\begin{array}{l}\text { Thermal } \\
\text { ALD }\end{array}$ & $\begin{array}{l}\text { Thermal } \\
\text { ALD }\end{array}$ & PEALD \\
\hline Substrate & P-type Si & - & $(100) \mathrm{Si}$ & (100) Si & P-type Si & (100) Si & P-type Si \\
\hline $\begin{array}{c}\text { Thickness } \\
{[\mathrm{nm}]}\end{array}$ & 42 & 7 & $6 \sim 11$ & $3.3 \sim 19$ & 4.3 & $5.9 \sim 6.5$ & $31.2 \sim 33.1$ \\
\hline $\begin{array}{l}\text { Annealing } \\
\text { Condition }\end{array}$ & - & $\begin{array}{c}250{ }^{\circ} \mathrm{C}, \\
\operatorname{Air}(1 \mathrm{~h})\end{array}$ & - & - & $\begin{array}{l}450{ }^{\circ} \mathrm{C}, \mathrm{N}_{2}+ \\
\mathrm{H}_{2}(30 \mathrm{~min})\end{array}$ & - & $\begin{array}{c}600^{\circ} \mathrm{C}, \mathrm{N}_{2} \\
(2 \mathrm{~h})\end{array}$ \\
\hline $\begin{array}{l}\text { Leakage } \\
\text { Current } \\
\text { Density } \\
{\left[\mathrm{A} / \mathrm{cm}^{2}\right]}\end{array}$ & $\begin{array}{c}\sim 107 \sim 108 \\
\text { (at } 1 \mathrm{MV} / \mathrm{cm} \text { ) }\end{array}$ & $\begin{array}{c}2 \times 10^{-1} \\
(\text { at }-1.5 \mathrm{~V})\end{array}$ & $\begin{array}{l}8 \times 10^{-3} \\
(\text { at } 1 \mathrm{~V})\end{array}$ & $\begin{array}{c}10^{-6} \\
\text { (at } 1 \mathrm{MV} / \mathrm{cm} \text { ) }\end{array}$ & $\begin{array}{l}2 \times 10^{-3} \\
(\text { at }-1 \mathrm{~V})\end{array}$ & $10^{-7}($ at $1 \mathrm{~V})$ & $\begin{array}{c}7.8 \times 10^{-8} \\
(\text { at }-1 \\
\mathrm{MV} / \mathrm{cm})\end{array}$ \\
\hline $\begin{array}{c}\text { Breakdown } \\
\text { Electric Field } \\
{[\mathrm{MV} / \mathrm{cm}]}\end{array}$ & $2 \sim 2.5$ & - & - & $1.9 \sim 9.5$ & - & - & $-3.9 \sim-4.7$ \\
\hline $\begin{array}{l}\text { Dielectric } \\
\text { Constant }\end{array}$ & $18-24$ & 22 & $12 \sim 18$ & 12.5 & 14 & $26-28$ & $20-25$ \\
\hline$\Delta \mathbf{V}_{\mathrm{FB}}[\mathrm{V}]$ & - & 0.03 & - & 0.25 & - & - & $0.6 \sim 2$ \\
\hline Reference & [18] & [19] & [23] & [30] & [31] & [32] & This work \\
\hline
\end{tabular}

The $\mathrm{ZrO}_{2}$ thin films were applied to the anode composites of SOFCs composed of $\mathrm{Ni}$ and YSZ composite. In order to probe the presence of $\mathrm{ZrO}_{2}$ materials in the reduced $\mathrm{Ni}$ /YSZ composites, an XPS analysis was performed. The presence of the $\mathrm{Zr}$ element in the relatively higher concentration near the Ni/YSZ composite surface enabled one to differentiate the deposited $\mathrm{ZrO}_{2}$ thin films deposited using CMEN-Zr and oxygen plasma. It is speculated that the ALD-based $\mathrm{ZrO}_{2}$ can be deposited into the pore networks formed in the Ni/YSZ anode composites. To probe the effect of ALD-based $\mathrm{ZrO}_{2}$ on the anode performance, three cases were tested, including ALD-based $\mathrm{ZrO}_{2}$ thin films with 50 cycles and 200 cycles along with the reference anode without any presence of $\mathrm{ZrO}_{2}$ thin films. Additionally, respective samples were tested to measure the cell performance, and then $\mathrm{ZrO}_{2}$ thin films were applied to the reduced Ni/YSZ anodes, as described above.

The measured cell performances are shown in Figure 11 as a function of operating temperature and $\mathrm{ZrO}_{2}$ cycles. The presence of 50-cycled $\mathrm{ZrO}_{2}(4.7 \mathrm{~nm})$ did not influence the SOFC performance. However, the 200-cycled $\mathrm{ZrO}_{2}$ materials significantly deteriorated the cell performance in terms of open circuit voltages and maximum power. The extracted information is shown in Figure 12. At $800^{\circ} \mathrm{C}$, the maximum power decreased from 1284 to $1075 \mathrm{~mW}$ for the 200 cycled $\mathrm{ZrO}_{2}$ films compared to the first cell test, which involved no coating of $\mathrm{ZrO}_{2}$ nanomaterials, and so the maximum decreased from 1219 to $1133 \mathrm{~mW}$ for 50-cycled $\mathrm{ZrO}_{2}$. In contrast, the standard reference cell showed powers of 1017 and $1039 \mathrm{~mW}$ for successive cell characterizations. In other words, the presence of $\mathrm{ZrO}_{2}$ nanomaterials onto the cathode system degraded the cell performance of SOFC unit cells. The corresponding open cell voltages were also reduced by an approximately similar magnitude before and after coating of $\mathrm{ZrO}_{2}$, as shown in Figure 12 between $1.10 \mathrm{~V}$ and $1.02 \mathrm{~V}$. The presence of $\mathrm{ZrO}_{2}$ materials does not affect the open cell voltage (OCV) due to the relative independence of OCV from the electrode responses. The presence of $\mathrm{ZrO}_{2}$ materials can be depicted schematically, as in Figure 13. The presence of $\mathrm{ZrO}_{2}$ nanomaterials can be deposited at triple phase boundaries on electronic conductors (i.e., metallic nickel), ionic conductor YSZ, and gaseous phase involving $\mathrm{H}_{2}$ and $\mathrm{H}_{2} \mathrm{O}$. The following electrochemical reaction usually takes place:

$$
2 \mathrm{H}_{2}+2 \mathrm{O}^{2-} \rightarrow 2 \mathrm{H}_{2} \mathrm{O}+4 \mathrm{e}^{-}
$$



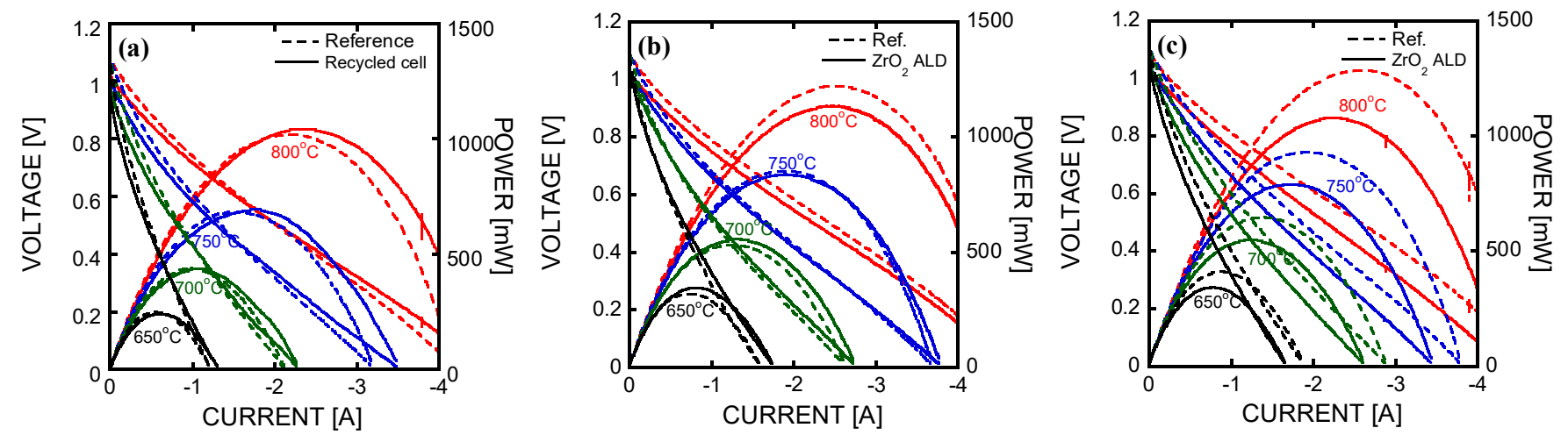

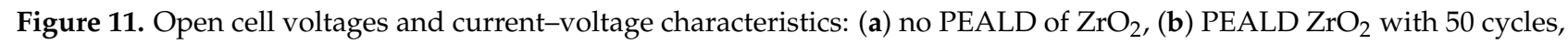
and (c) PEALD $\mathrm{ZrO}_{2}$ with 200 cycles.
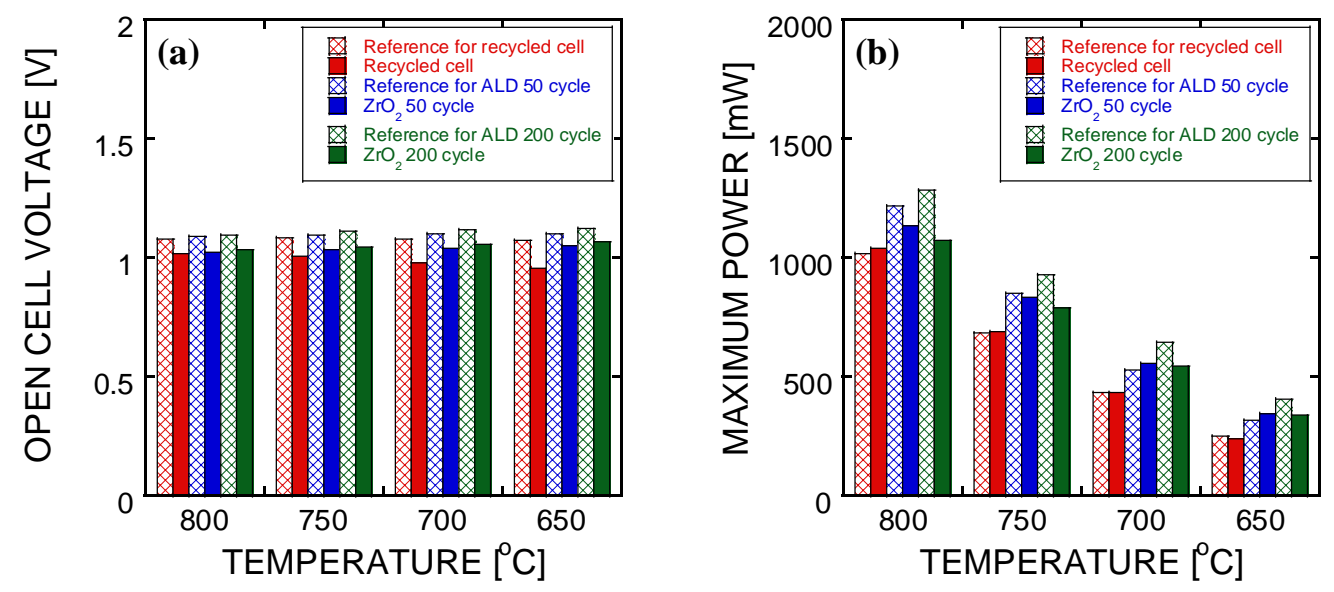

Figure 12. (a) Open cell voltages of reference cells and $\mathrm{ZrO}_{2}$ ALD cells, (b) maximum power of reference cells and $\mathrm{ZrO}_{2}$ ALD cells.

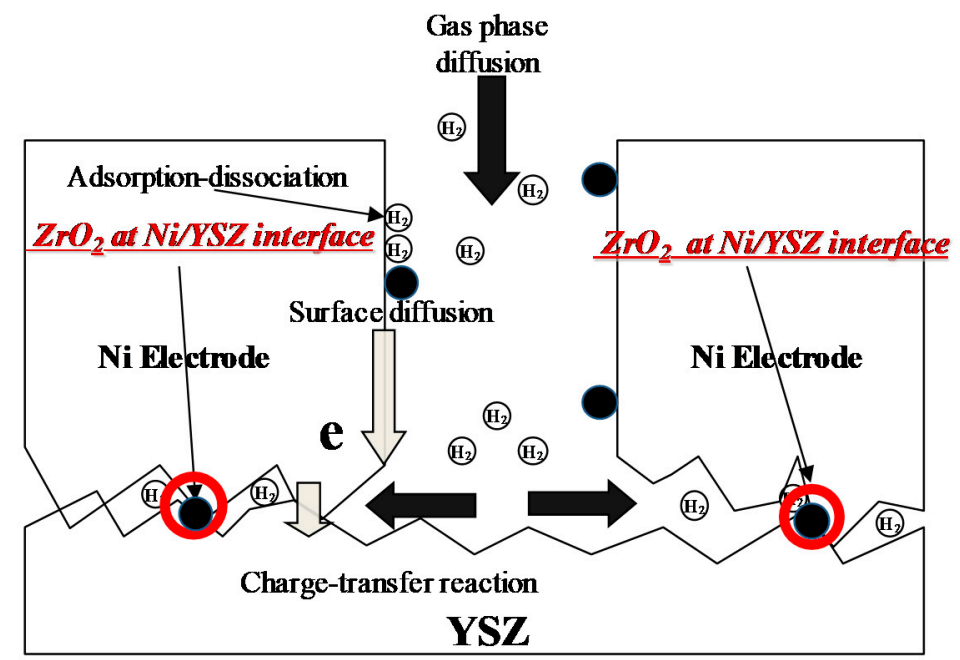

Figure 13. Schematic diagram describing the role of ALD-based $\mathrm{ZrO}_{2}$ nanomaterials in the electrochemical performances of SOFC anodes.

The presence of $\mathrm{ZrO}_{2}$ nanomaterials decreases the effective density of triple phase boundaries by reducing the resultant electrochemical performance.

Impedance spectroscopy analysis was performed in terms of equivalent circuits, incorporating the ohmic resistances and electrode-related responses composed of high-frequency, medium-frequency, and low-frequency regimes. The electrochemical impedance is mod- 
eled using equivalent notation, which is described by $\mathrm{R}_{0}\left(\mathrm{R}_{\text {high }} \mathrm{CPE} \mathrm{E}_{\text {high }}\right)\left(\mathrm{R}_{\text {med }} C P E_{\text {med }}\right)$ $\left(\mathrm{R}_{\text {low }} C P E_{\text {low }}\right)$, where $\mathrm{R}_{0}$ is the ohmic resistance, and $\mathrm{R}_{\text {high }}, \mathrm{R}_{\text {med }}, \mathrm{R}_{\text {low }}$ and $\mathrm{CPE}$ high, $C P E_{\text {med }}$, and $\mathrm{CPE}_{\text {low }}$ are the resistances and constant phase elements, at high, medium, and lowfrequency regimes, respectively. The ohmic resistances coexist with three parallel RC components, denoted by $\left(\mathrm{R}_{\mathrm{i}} \mathrm{CPE} \mathrm{E}_{\mathrm{i}}\right)$ using parenthesis. In particular, this presence does not seem to influence the overall ohmic resistances and instead affects the electrode-related responses, especially high-frequency responses, compared to the remaining frequency responses. SOFCs have attracted academic and industrial interests as one of the powerful next generation energy resources due to their unique advantages such as high operation efficiency, contamination-free fuel flexibility, and minimized pollution. SOFCs are typically constructed using materials with dissimilar physical and chemical properties, including cathodes, electrolytes, and anodes, in addition to the subsidiary sealing and interconnect materials.

To achieve highly efficient operation of SOFCs at intermediate temperatures ranging from 650 and $800{ }^{\circ} \mathrm{C}$, the electrodes, i.e., cathodes and anodes, should be improved dramatically by minimizing polarization loss of composite electrodes in addition to improving ionic conductivity in electrolytes. There has been a highly limited number of empirical attempts involving artificial controls on triple boundary reactions based on the charge transfer between electronic/ionic carries and fuels. This approach depends largely on the microstructure of electrodes and interfacial geometries adjacent to the ionic electrolyte in combination with triple phase boundaries and their contributions to electrochemical reactions at both the anodes and cathodes. Although the current work was applied to $\mathrm{Ni}$ /YSZ anode composites of SOFCs, the conformal feature of atomic layer deposition can be employed to control oxide-based cathodes and anodes as well in terms of performance improvement or performance degradation, depending on the beneficial and detrimental influences. The current study reports the success of atomic layer deposition combined with solid oxide fuel cells, with special emphasis on the triple phase boundaries. The current work chose metal oxide materials for controlling the SOFC anodes.

\section{Conclusions}

$\mathrm{ZrO}_{2}$ thin films were successfully deposited through plasma-enhanced atomic layer deposition using (2-(N-methylamino)1-MethylEthyleneCyclopentadienyl)Bis(Dimethylamino)Zr (abbreviated as CMEN-Zr) as Zr sources and oxygen plasma as oxygen sources. The conformal deposition of insulating and the quasi-crystalline zirconium oxide nanomaterials were applied to the Ni/YSZ anode composites of solid oxide fuel cells. The atomic layer deposition of functional oxide materials can be in the structurally controlled manner deposited to the anode composites in the solid oxide fuel cells. The ALD-based $\mathrm{ZrO}_{2}$ functions as an inhibitor for the electrode reactions at the triple phase boundaries (TPBs) of SOFCs, thus decreasing the maximum power. The understanding of the ALD-assisted $\mathrm{ZrO}_{2}$ coating in association with the degraded electrochemical performance can be employed in searching for the synergistic materials (or catalytic materials). However, this approach should be tested for long-time stability issues in future studies.

Author Contributions: Conceptualization and formal analysis, J.O. and G.S.; investigation, J.K.; methodology, S.B.; supervision J.-W.P.; writing-original draft preparation and supervision, J.-H.H. All authors have read and agreed to the published version of the manuscript.

Funding: This research was supported by Basic Science Research Programs through the National Research Foundation of Korea (NRF) funded by Ministry of Education (NRF-2016R1D1A1B01015557). This research was also supported by a National Research Foundation of Korea (NRF) grant funded by the Ministry of Science and ICT for convergent research in Development program for convergence R\&D over traditional culture and current technology (NRF-2016M3C1B5906486), by Nano Material Technology Development Program through the National Research Foundation of Korea (NRF) funded by Ministry of Science and ICT (NRF-2021M3A7B4021104), and by the Multi-Ministry Collaborative R\&D Program (Development of Techniques for Identification and Analysis of Gas Molecules to 
Protect Against Toxic Substances) through the National Research Foundation of Korea (NRF) funded by KNPA, MSIT, MOTIE, ME, and NFA (NRF-2020M3D9A1080706).

Institutional Review Board Statement: Not applicable.

Informed Consent Statement: Not applicable.

Data Availability Statement: The data of this work are available upon request to the corresponding author.

Conflicts of Interest: The authors declare no conflict of interest.

\section{References}

1. Ormerod, R.M. Solid oxide fuel cells. Chem. Soc. Rev. 2003, 32, 17-28. [CrossRef]

2. Minh, N.Q. Solid oxide fuel cell technology-features and applications. Solid State Ion. 2004, 174, 271-277. [CrossRef]

3. Jacobson, A.J. Materials for solid oxide fuel cells. Chem. Mater. 2010, 22, 660-674. [CrossRef]

4. Yamamoto, O. Solid oxide fuel cells: Fundamental aspects prospects. Electrochim. Acta 2000, 45, 2423-2435. [CrossRef]

5. Zhu, W.; Ding, D.; Xia, C. Enhancement in three-phase boundary of SOFC electrodes by and ion impregnation method: A modeling comparison. Electrochem. Solid-State Lett. 2008, 11, B83-B86. [CrossRef]

6. Li, C.; Lee, E.K.; Kim, Y.T.; Lee, D. Enhancing triple-phase boundary at fuel electrode of direct carbon fuel cell using a fuel-filled ceria-coated porous anode. Int. J. Hydrog. Energy 2014, 39, 17314-17321. [CrossRef]

7. Dusastre, V.; Kilner, J.A. Optimisation of composite cathodes for intermediate temperature SOFC applications. Solid State Ion. 1999, 126, 163-174. [CrossRef]

8. Suntola, T. Atomic layer epitaxy. Mater. Sci. Rep. 1989, 4, 261-312. [CrossRef]

9. Zaera, F. The surface chemistry of thin film atomic layer deposition (ALD) processes for electronic device manufacturing. J. Mater Chem. 2008, 18, 3521-3526. [CrossRef]

10. Berthelot, A.; Caillat, C.; Huard, V.; Barnola, S.; Boeck, B.; Del-Puppo, H.; Emonet, N.; Lalanne, F. Highly reliable TiN/ZrO $2 /$ TiN 3D stacked capacitors for $45 \mathrm{~nm}$ embedded DRAM technologies. In Proceedings of the ESSDERC 2006-Proceedings of the 36th European Solid-State Device Research Conference, Montreux, Switzerland, 19-21 September 2006; pp. 343-346.

11. Wang, Z.; Zhu, W.G.; Du, A.Y.; Wu, L.; Fang, Z.; Tran, X.A.; Liu, W.J.; Zhang, K.L.; Yu, H.Y. Highly uniform, self-compliance, and forming-free $\mathrm{ALD} \mathrm{HfO}_{2}$-based RRAM with Ge doping. IEEE Trans. Electron Devices 2012, 59, 1203-1208. [CrossRef]

12. Xuan, Y.; Wu, Y.Q.; Shen, T.; Yang, T.; Ye, P.D. High performance submicron inversion-type enhancement-mode InGaAs MOSFETs with $\mathrm{ALD} \mathrm{Al}_{2} \mathrm{O}_{3}, \mathrm{HfO}_{2}$ and $\mathrm{HfAlO}$ as gate dielectrics. In Proceedings of the Technical Digest-International Electron Devices Meeting, IEDM, Washington, DC, USA, 10-12 December 2007; pp. 637-640.

13. Boyadjiev, S.; Georgieva, V.; Vergov, L.; Baji, Z.; Gáber, F.; Szilágyi, I.M. Gas sensing properties of very thin $\mathrm{TiO}_{2}$ films prepared by atomic layer deposition (ALD). Proc. J. Phys. Conf. Ser. 2014, 559, 012013. [CrossRef]

14. Seo, S.; Jeong, S.; Park, H.; Shin, H.; Park, N.G. Atomic layer deposition for efficient and stable perovskite solar cells. Chem. Commun. 2019, 55, 2403-2416. [CrossRef]

15. Pickrahn, K.L.; Gorlin, Y.; Seitz, L.C.; Garg, A.; Nordlund, D.; Jaramillo, T.F.; Bent, S.F. Applications of ALD MnO to electrochemical water splitting. Phys. Chem. Chem. Phys. 2015, 17, 14003-14011. [CrossRef]

16. Pavlenko, M.; Siuzdak, K.; Coy, E.; Załęski, K.; Jancelewicz, M.; Iatsunskyi, I. Enhanced solar-driven water splitting of 1D core-shell Si/ $\mathrm{TiO}_{2} / \mathrm{ZnO}$ nanopillars. Int. J. Hydrogen Energy 2020, 45, 26426-26433. [CrossRef]

17. Neudeck, S.; Mazilkin, A.; Reitz, C.; Hartmann, P.; Janek, J.; Brezesinski, T. Effect of low-temperature $\mathrm{Al}_{2} \mathrm{O}_{3} \mathrm{ALD}_{\mathrm{L}}$ coating on Ni-rich layered oxide composite cathode on the long-term cycling performance of lithium-ion batteries. Sci. Rep. 2019, 9, 5328. [CrossRef] [PubMed]

18. Cassir, M.; Goubin, F.; Bernay, C.; Vernoux, P.; Lincot, D. Synthesis of $\mathrm{ZrO}_{2}$ thin films by atomic layer deposition: Growth kinetics, structural and electrical properties. Appl. Surf. Sci. 2002, 193, 120-128. [CrossRef]

19. Kukli, K.; Forsgren, K.; Ritala, M.; Leskelä, M.; Aarik, J.; Hårsta, A. Dielectric properties of zirconium oxide grown by atomic layer deposition from iodide precursor. J. Electrochem. Soc. 2001, 148, F227-F232. [CrossRef]

20. Lao, S.X.; Martin, R.M.; Chang, J.P. Plasma enhanced atomic layer deposition of $\mathrm{HfO}_{2}$ and $\mathrm{ZrO}_{2}$ high-k thin films. J. Vac. Sci. Technol. A Vac. Surf. Film. 2005, 23, 488-496. [CrossRef]

21. Hausmann, D.M.; Kim, E.; Becker, J.; Gordon, R.G. Atomic layer deposition of hafnium and zirconium oxides using metal amide precursors. Chem. Mater. 2002, 14, 4350-4358. [CrossRef]

22. Yun, S.J.; Lim, J.W.; Lee, J.H. PEALD of zirconium oxide using tetrakis(ethylmethylamino) zirconium and oxygen. Electrochem. Solid-State Lett. 2004, 7, F81-F84. [CrossRef]

23. Blanquart, T.; Niinistö, J.; Aslam, N.; Banerjee, M.; Tomczak, Y.; Gavagnin, M.; Longo, V.; Puukilainen, E.; Wanzenboeck, H.D.; Kessels, W.M.M.; et al. $\left.\mathrm{Zr}(\mathrm{NEtMe})_{2}(\text { guan-NEtMe })_{2}\right]$ as a novel atomic layer deposition precursor: $\mathrm{ZrO}_{2}$ film growth and mechanistic studies. Chem. Mater. 2013, 25, 3088-3095. [CrossRef]

24. Jung, J.S.; Lee, S.K.; Hong, C.S.; Shin, J.H.; Kim, J.M.; Kang, J.G. Atomic layer deposition of $\mathrm{ZrO}_{2}$ thin film on Si(100) using \{ $\eta$ : $\left.1-\mathrm{Cp}\left(\mathrm{CH}_{2}\right)_{3} \mathrm{NMe}\right\} \mathrm{Zr}\left(\mathrm{NMe}_{2}\right)_{2} / \mathrm{O}_{3}$ as precursors. Thin Solid Film. 2015, 589, 831-837. [CrossRef] 
25. Kanomata, K.; Tokoro, K.; Imai, T.; Pansila, P.; Miura, M.; Ahmmad, B.; Kubota, S.; Hirahara, K.; Hirose, F. Room-temperature atomic layer deposition of $\mathrm{ZrO}_{2}$ using tetrakis(ethylmethylamino) zirconium and plasma-excited humidified argon. Appl. Surf. Sci. 2016, 387, 497-502. [CrossRef]

26. Roy, P.C.; Jeong, H.S.; Doh, W.H.; Kim, C.M. Atomic layer deposition (ALD) of $\mathrm{ZrO}_{2}$ in ultrahigh vacuum (UHV). Bull. Korean Chem. Soc. 2013, 34, 1221-1224. [CrossRef]

27. Weinreich, W.; Tauchnitz, T.; Polakowski, P.; Drescher, M.; Riedel, S.; Sundqvist, J.; Seidel, K.; Shirazi, M.; Elliott, S.D.; Ohsiek, $\mathrm{S}$; , et al. TEMAZ $/ \mathrm{O}_{3}$ atomic layer deposition process with doubled growth rate and optimized interface properties in metalinsulator-metal capacitors. J. Vac. Sci. Technol. A Vac. Surf. Film. 2013, 31, 01A123. [CrossRef]

28. Dey, S.K.; Wang, C.G.; Tang, D.; Kim, M.J.; Carpenter, R.W.; Werkhoven, C.; Shero, E. Atomic layer chemical vapor deposition of $\mathrm{ZrO}_{2}$-based dielectric films: Nanostructure and nanochemistry. J. Appl. Phys. 2003, 93, 4144-4157. [CrossRef]

29. Wiemer, C.; Debernardi, A.; Lamperti, A.; Molle, A.; Salicio, O.; Lamagna, L.; Fanciulli, M. Influence of lattice parameters on the dielectric constant of tetragonal $\mathrm{ZrO}_{2}$ and La-doped $\mathrm{ZrO}_{2}$ crystals in thin films deposited by atomic layer deposition on Ge (001). Appl. Phys. Lett. 2011, 99, 232907. [CrossRef]

30. Putkonen, M.; Niinist, J.; Kukli, K.; Sajavaara, T.; Karppinen, M.; Yamauchi, H.; Niinist, L. ZrO 2 thin films grown on silicon substrates by atomic layer deposition with $\mathrm{Cp}_{2} \mathrm{Zr}\left(\mathrm{CH}_{3}\right)_{2}$ and water as precursors. Chem. Vap. Depos. 2003, 9, 207-212. [CrossRef]

31. Lee, B.; Choi, K.J.; Hande, A.; Kim, M.J.; Wallace, R.M.; Kim, J.; Suydam, J. A novel thermally-stable zirconium amidinate ALD precursor for $\mathrm{ZrO}_{2}$ thin films. Microelectron. Eng. 2009, 86, 272-276. [CrossRef]

32. Niinist, J.; Kukli, K.; Kariniemi, M.; Ritala, M.; Leskel, M.; Blasco, N.; Dussarrat, C. Novel mixed alkylamido-cyclopentadienyl precursors for ALD of $\mathrm{ZrO}_{2}$ thin films. J. Mater. Chem. 2008, 18, 5243-5247. [CrossRef] 